\title{
HMG-CoA Reductase Inhibitory Activity of Garcinia latissima Miq. Mesocarp Water Extract for Herbal Tea
}

\author{
Herra Williany Monalissa, Berna Elya*, Nuraini Puspitasari
}

\section{Herra Williany Monalissa, Berna Elya*, Nuraini Puspitasari}

Department of Pharmacognosy and Phytochemistry, Faculty of Pharmacy, Universitas Indonesia Depok, 16424, West Java, INDONESIA.

\section{Correspondence}

\section{Mrs. Berna Elya}

Departmen of Pharmacognosy and Phytochemistry, Faculty of Pharmacy, Universitas Indonesia Depok, 16424, West Java, INDONESIA.

Phone no : +6281314161497

E-mail: berna.elya@farmasi.ui.ac.id

\section{History}

- Submission Date: 03-06-2018.

- Review completed: 07-08-2018;

- Accepted Date: 03-10-2018

DOI : 10.5530/pj.2018.6s.26

Article Available online http://www.phcogj.com/v10/i6s

\section{Copyright}

(c) 2018 Phcog.Net. This is an openaccess article distributed under the terms of the Creative Commons Attribution 4.0 International license.

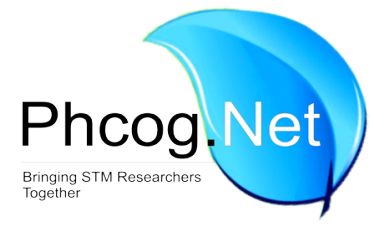

\begin{abstract}
Context: High cholesterol in the blood is a risk factor for atherosclerosis that causes various diseases. The main pharmacologic intervention to reduce cholesterol levels is inhibiting the HMG-CoA reductase enzyme. One of the genera of Garcinia, Garcinia dulcis, has potential as an anti-cholesterol. Based on chemotaxonomy, Garcinia latissima Miq. is also estimated to have a potency as anti-cholesterol. Aims: This study aims to test the inhibition of HMG-CoA reductase water extract activity of $G$. latissima fruit flesh with different duration of infusions. Materials and Methods: Garcinia latissima Miq. mesocarp was extracted using infusion method with different duration of infusions. Each of extracts was tested the inhibitory activity of HMG-CoA reductase as well as the determination of total flavonoid and total phenol content. In addition, the simplicia of the mesocarp of G.latissima Miq. will be made as a herbal tea and a hedonic test is performed to find out the degree of liking for the tea. Result: The test results showed the inhibitory activity of 100 ppm G. latissima Miq. mesocarp water extract with infusion for 5,10 and $15 \mathrm{~min}$ respectively $11.32 ; 29.02 ; 13.03 \%$. The 10 min extract with the largest enzyme inhibition had total flavonoids content of $31.24 \mathrm{mg}$ QE / gram extract and total phenol content of $4.64 \mathrm{mg} \mathrm{GAE} /$ gram extract. The result of the hedonic test for the colour, aroma, flavour of herbal tea formula A respectively $30 ; 30 ; 20 \%$ and formula B respectively for $40 ; 33.3 ; 50 \%$. Conclusion: The water extract of G.latissima Miq mesocarp has a low potency in $\mathrm{HMG}-\mathrm{CoA}$ reductase inhibitory activities.

Key words: Anti Cholesterol, Garcinia latissima, Herbal Tea, HMG-CoA reductase, Mesocarp.
\end{abstract}

\section{INTRODUCTION}

Cholesterol has an important role in life. High levels of total cholesterol in the blood or hypercholesterolemia play a role in the pathology process as a risk factor for atherosclerosis that causes various diseases such as, cerebrovascular, coronary and peripheral blood vessels. ${ }^{1}$ The main pharmacologic intervention used to reduce cholesterol levels is to inhibit the HMG-CoA enzyme that catalyses HMG-CoA changes to mevalonate in the cholesterol biosynthesis pathway. ${ }^{2}$

Indonesia has a high variety of Garcinia (Garcinia spp.) Species. ${ }^{3}$ Garcinia plants have been utilized by the community empirically in various forms such as the utilization of Garcinia plants as tea. A tea has been made from the fruit of $G$. mangostana which can be used as a tonic to overcome fatigue. ${ }^{4}$ Tea can improve the taste of the ingredients used without reducing the efficacy. ${ }^{5}$

The efficacy of the garcinia plant is not only proven empirically but also scientifically. From several studies that have been conducted on various types of Garcinia plants, Garcinia has a variety of pharmacologically useful activities for the treatment of certain diseases. Pharmacologic activity in Garcinia is antidiabetic and antioxidant, anticancer, antimalarial, antifungal, antibacterial, anti-inflammatory, as well as for the treatment of dysentery, diarrhoea and ulcers. ${ }^{6}$ Research on the anti-cholesterol activity of Garcinia plant that can be used in helping the treatment of hypercholesterolemia is still rarely studied. One of Garcinia plant that has been studied is Garcinia dulcis. Biflavonoid from Garcinia dulcis has a constant inhibitory activity against HMG-CoA reductase enzyme of $80.87 \pm$ $0.06 \mu \mathrm{m} .{ }^{7}$

Based on the above description, it is necessary to do further research on the activity of anti-cholesterol from Garcinia latissima Miq. and herbal tea will be made from the plant. Based on the consideration of chemotaxonomy, Garcinia latissima Miq. Is expected to inhibit HMG-CoA enzyme activity.

This study aims to determine the inhibitory of HMG-CoA reductase activity of G. latissima fruit water extract with different duration of infusion, as well as the determination of total flavonoid and phenol contents in the extract. In addition, simplicia G. latissima Miq. mesocarp will be made in the form of tea and a hedonic test is performed.

\section{MATERIALS AND METHODS}

\section{Materials}

Garcinia latissima Miq. fruit collected from Bogor Botanical Garden, Indonesia and determined by

Cite this article: Monalissa HW, Elya B, Puspitasari N. HMG-CoA Reductase Inhibitory Activity of Garcinia latissima Miq. Mesocarp Water Extract for Herbal Tea. Pharmacog J. 2018;10(6) Suppl:s141-s146. 
Lembaga Ilmu Pengetahuan Indonesia, Bogor. Pravastatin (Sigma Aldrich), Quercetin (Sigma Aldrich) and Galic Acid (Sigma Aldrich), HMG-CoA reductase assay Kit CS 1090 (Sigma Aldrich), aquadest, chloroform $\mathrm{P}$, acetone $\mathrm{P}$, formic acid $\mathrm{P}$, methanol $\mathrm{P}$, ethanol $\mathrm{P}$, folin-ciocalteu phenol LP, chloride acid LP, potassium phosphate, potassium dihydrogen phosphate and $\mathrm{NaOH}$.

\section{Preparation of Simplicia}

Garcinia latissima Miq. fruit collected and sorted wetly from dirt. Fruits were separated from seeds and fruit flesh. Fruit fleshes were picked and dried in the drying cupboard. After drying, simplicia were sorted dryly to separate simplicia with other material. Then simplicia was powdered.

\section{Characterization of Simplicia Organoleptic test}

Simplicia powder of Garcinia latissima Miq. was described as shape, colour and taste using the sensory. ${ }^{8}$

\section{Water soluble extract}

Five g of simplicia powder was weighed and put in a clogged flask, add $100 \mathrm{~mL}$ water-chloroform P shaken constantly for the first $6 \mathrm{~h}$, then left for $18 \mathrm{~h}$. $20 \mathrm{ml}$ of filtrate were evaporated in a tared flat dishes, the rest of filtrate was heated in $105^{\circ} \mathrm{C}$ until constant mass. ${ }^{8}$

\section{Ethanol soluble extract}

Five gram of simplicia powder was weighed accurately and put in a clogged flask, add $100 \mathrm{~mL}$ ethanol $95 \%$ P, shook constantly for the first $6 \mathrm{~h}$, then left for $18 \mathrm{~h} .20 \mathrm{ml}$ of filtrate were evaporated in a tared flat dishes, the rest of filtrate was heated in $105^{\circ} \mathrm{C}$ until constant mass. ${ }^{8}$

\section{Total ash content}

Two gram of simplicia powder was weighed accurately and put in a tared silica crucible, incinerate gradually until free from carbon, cool in the desiccator and weighed. Total ash content is calculated from the weight of the sample was taken and expressed in \% w/w. ${ }^{8}$

\section{Acid-Insoluble Ash Content}

Boil the ash obtained as directed in Total ash with $25 \mathrm{~mL}$ diluted hydrochloric acid for $5 \mathrm{~min}$. The insoluble matters were collected and filtered through the ashless filter, washed with hot water, ignite in the crucible until constant weight. Acid-insoluble ash was calculated from the weight of the sample was taken and expressed in $\% \mathrm{w} / \mathrm{w} .^{8}$

\section{Loss on drying}

The weighing bottle was prepared and heated at $105^{\circ} \mathrm{C}$ for $30 \mathrm{~min}$, then weighed. The bottle was heated again at $105^{\circ} \mathrm{C}$ for $30 \mathrm{~min}$ the weighed until constant mass. After that, simplicia powder was weighed $1 \mathrm{~g}$ accurately than was heated at $105^{\circ} \mathrm{C}$ for $5 \mathrm{~h}$ and was weighed again. Drying process was continued and was weighted again for one hour until the difference in two successive weighings is less than $0,25 \%{ }^{8}$

\section{Extraction}

Each two gram simplicia powder extracted using infusion method for 5, 10 and $15 \mathrm{~min}$. After extraction, the result was filtered and was dried using freeze dryer to obtain a dry extract.

\section{HMG-CoA Reductase Inhibitory Activity Test}

The commercially available HMG-CoA reductase assay kit from SigmaAldrich was used to screen HMG-CoA reductase inhibitory activity. The test was performed three repetitions using microplate reader at $37^{\circ} \mathrm{C}$. Each extract was added DMSO then dissolved in phosphate buffer solution $\mathrm{pH} 7,4$. A $0.2 \mathrm{~mL}$ reaction mixture containing $1 \mathrm{~mL}$ of the solutions of the extracts, $4 \mathrm{~mL}$ of reconstituted NADPH, $12 \mathrm{~mL}$ of HMG-CoA solution and $2 \mathrm{~mL}$ HMG-CoA reductase was shaken mechanically in the plate reader for 10s. Then, the solution was measured its absorbance at $340 \mathrm{~nm}$ every $20 \mathrm{sec}$ for $10 \mathrm{~min}$. HMG-CoA reductase inhibitory activity was calculated using the following formula:

$$
\% \mathrm{HMG}-\mathrm{CoA} \text { reductase inhibitory activity : } \frac{(\mathrm{A}-\mathrm{B})-(\mathrm{C}-\mathrm{D})}{\mathrm{A}-\mathrm{B}} \times 100
$$

$\mathrm{A}=\Delta$ Positive blank absorbance; $\mathrm{B}=\Delta$ Negative blank absorbance, $\mathrm{C}=\Delta$ Sample absorbance, $\mathrm{D}=\Delta$ Sample blank absorbance

\section{Thin Layer Chromatography Profile}

Thin Layer Chromatography was performed with mobile phase Chloroform P-Acetone P-Formic Acid (10:2:1), stationary phase Silica gel $60 \mathrm{~F}_{254}$. Sample solution $5 \%$ in ethanol P and standard solution $0,01 \%$ in ethanol P. Spotted volume of sample solution $30 \mu \mathrm{L}$ and standard solution $5 \mu \mathrm{L}$. The chromatogram was sprayed with Aluminium chloride $5 \%$ and identified using UV detection at $365 \mathrm{~nm}$.

\section{Determination of Total Flavonoid Content}

Samples were analysed spectrophotometrically for the contents of total flavonoid using FHI method and quercetin as standard. Sample solutions were added internal standard. Each 0,5 $\mathrm{mL}$ standard and sample solution were separately mixed with $1,5 \mathrm{~mL}$ ethanol $\mathrm{P}, 0,1 \mathrm{~mL} \mathrm{AlCl}{ }_{3} 10 \%(\mathrm{w} / \mathrm{v})$, $0,1 \mathrm{~mL}$ Natrium acetate $1 \mathrm{M}$ and $2,8 \mathrm{~mL}$ aquadest. After incubation at room temperature for $30 \mathrm{~min}$, the absorbance of the mixture was measured at a maximum wave. Each mixture was measured in three repetitions.

\section{Determination of Total Phenolic Content}

Samples were analysed spectrophotometrically for the contents of total phenolic using Folin Ciolcalteu method and gallic acid as standard. Sample solutions were added internal standard. Each one $\mathrm{mL}$ standard and sample solution were separately diluted in $5 \mathrm{~mL}$ Folin-ciocalteu LP (7,5 \% in aquadest). The mixture was allowed to stand for $8 \mathrm{~min}$, then the mixture was added $4 \mathrm{~mL} \mathrm{NaOH} 1 \%$. After incubation at room temperature around $1 \mathrm{~h}$, the absorbance of the mixture was measured at a maximum wave. Each mixture was measured in three repetitions.

\section{Formulation of Herbal Tea and Preparation of Hedonic} Test

Two formulas of Garcinia latissima Miq Mesocarp herbal tea were made for the hedonic test. Formula A contained $\pm 2 \mathrm{~g}$ simplicia powder. Formula B contained $\pm 2 \mathrm{~g}$ simplicia powder and $\pm 0,35 \mathrm{~g}$ stevia. For hedonic test, $100 \mathrm{~mL}$ hot water was used to brew the tea. The herbal tea was brewed for several min adapted to duration of extract that had highest inhibitory activity.

\section{Hedonic test}

The hedonic test was performed with 30 untrained panellists. There is three parameter which will be valued namely taste, fragrance and colour. This hedonic test was used 6 hedonic scaled. $0=$ dislike; $1=$ neutral; 2 = like slightly; $3=$ like; 4 like very much; 5 =like extremely. Each panellists had herbal tea formula A and B in a plastic glass, mineral water as blanko and The assessment sheet. Data were analysed stastically with Mann-Whitney test using SPSS 20.0 Program.

\section{RESULT}

\section{Characterization of Simplicia}

The result of characterization of simplicia can be seen in Table 1. 
Table 1: The result of Characterization of Simplicia.

\begin{tabular}{ccc} 
No & Parameter & The test result \\
\hline 1. & Organoleptic & \\
& Shape & Dry powder \\
& Colour & Pink \\
& Odor & Specific odor \\
& Taste & Sour \\
2. & Water-Soluble Extract & $29,17 \pm 0,34 \%$ \\
4. & Total Ash Content & $4,80 \pm 0,13 \%$ \\
5. & Acid-insoluble ash content & $0,34 \pm 0,04 \%$ \\
6. & Loss on drying & $3,13 \pm 0,27 \%$ \\
\hline
\end{tabular}

Table 2: Yield presentation of G. latissima Miq. Mesocarp.

\begin{tabular}{cccc} 
Duration & $\begin{array}{c}\text { Extract Weight } \\
\text { (gram) }\end{array}$ & $\begin{array}{c}\text { Simplicia Extract } \\
\text { (gram) }\end{array}$ & Yield (\%) \\
\hline 5 Minutes & 0,61 & 2 & 30,5 \\
10 Minutes & 0,7 & 2,01 & 34,83 \\
15 Minutes & 0,68 & 2,01 & 33,83 \\
\hline
\end{tabular}

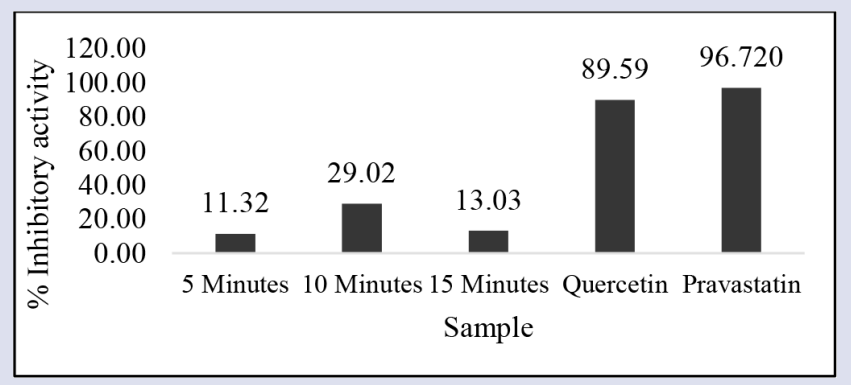

Figure 1: Graph of HMG-CoA Inhibitory activity percentage.

\section{Extraction}

10 min infusion extract had optimal yield presentation. Yield presentation decrease on extract with $15 \mathrm{~min}$ infusion. Yield presentation of all infusion can be seen in Table 2 .

\section{HMG-CoA Reductase Inhibitory Activity Test}

HMG-CoA Reductase Inhibitory Activity was done for each of samples and standard solution. There are 5 min infusion extract, $10 \mathrm{~min}$ infusion extract, $15 \mathrm{~min}$ infusion extract, quercetin and pravastatin. A preliminary test on pravastatin was performed to determine $\mathrm{IC}_{50}$ was also performed. The standard solution, pravastatin, was diluted into several concentrations and the calibration curve was made. The regression equation obtained is $y=0,2716 x+29,169$ with regression coefficient is 0,99984 . The calibration curve of pravastatin can be seen in Figure 2 and the dose of Pravastatin that used in the preliminary test can be seen in Table $3 . \mathrm{IC}_{50}$ was obtained from the test is $76,72 \mathrm{nM}$. IC50 pravastatin from previous is $66,5 \mathrm{nM}$, ${ }^{9}$ $70 \mathrm{nM}^{10}$ dan $87,76 \mathrm{nM}^{11}$

Based on the result,10 min infusion extract of G. latissimia Miq. mesocarp has the highest percentage HMG-CoA reductase inhibitory activity. Inhibitory activity percentage of all infusions extract, quercetin and pravastatin can be seen in Figure 1. Therefore, at Thin layer Chromatography profile was used $10 \mathrm{~min}$ infusion extract and at hedonic test duration of brewing is $10 \mathrm{~min}$.

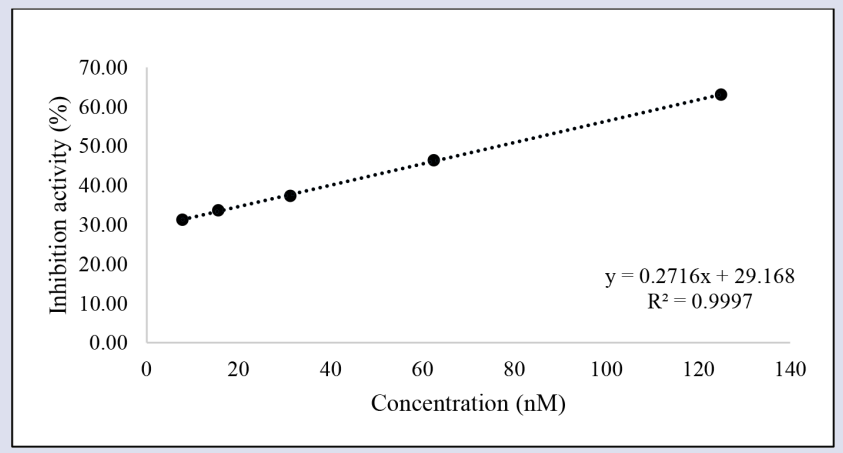

Figure 2: Calibration Curve of Pravastatin in $\lambda_{\max } 366 \mathrm{~nm}$.

Table 3: The Dose of Pravastatin In The Preliminary Test.

\begin{tabular}{cc}
\hline Concentration (nM) & Inhibitory Activity (\%) \\
\hline 125 & 63,07 \\
62,5 & 46,36 \\
31,25 & 37,30 \\
15,625 & 33,64 \\
7,8125 & 31,25 \\
\hline
\end{tabular}

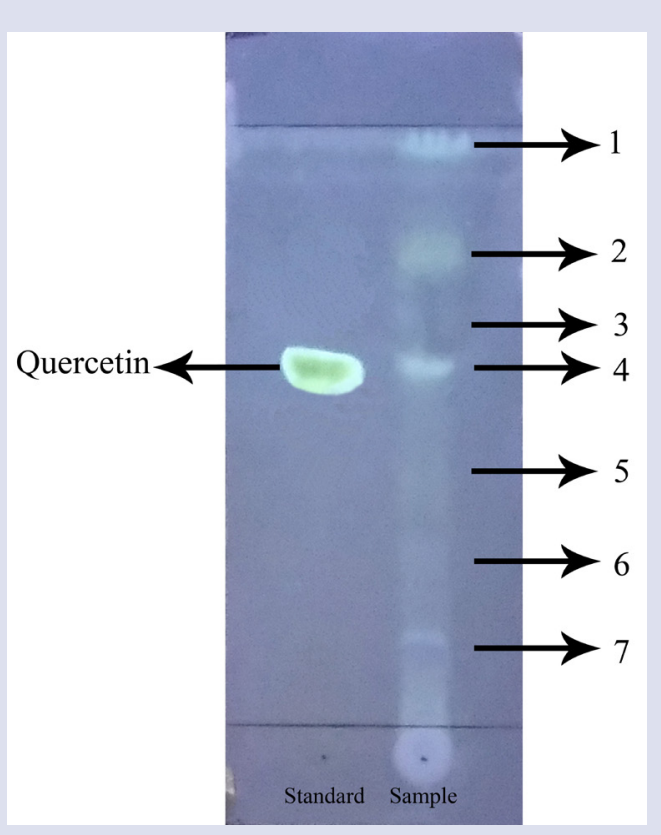

Figure 3: Chromatogram Profile of Quercetin and 10 min infusion water extract G. latissima Miq. mesocarp using mobile phase chloroform: acetone: formic acid (10:2:1) after was sprayed $\mathrm{AICl} 3$ on UV $366 \mathrm{~nm}$.

\section{Chromatogram Profile}

The result of chromatogram can be seen in the Figure 3 and Table 4 . Based on chromatogram profile at $10 \mathrm{~min}$ infusion water extract G. latissima Miq. Rf value of Quercetin is 0,58 and has yellow spot colour. The sample also had the same $\mathrm{Rf}$ value with Quercetin. There is an identical spot with standard and sample, so it can be concluded that $10 \mathrm{~min}$ infusion water extract contained flavonoid quercetin. 
Table 4: Chromatogram Profile of Quercetin and $10 \mathrm{~min}$ infusion water extract G. latissima Miq. mesocarp using mobile phase chloroform: acetone: formic acid (10:2:1) after was sprayed $\mathrm{AICl}_{3}$ on UV $366 \mathrm{~nm}$.

\begin{tabular}{ccc}
\hline Spot number & $\begin{array}{c}\text { Rf value } \\
\text { UV366 nm }\end{array}$ & Spot Colour \\
\hline Quercetin & 0,58 & yellow \\
1 & 0,97 & yellow \\
2 & 0,8 & yellow \\
3 & 0,7 & yellow \\
4 & 0,58 & yellow \\
5 & 0,42 & yellow \\
6 & 0,25 & yellow \\
7 & 0,1 & yellow \\
\hline
\end{tabular}

Table 5: Total Flavonoid Content of Water Extract of G.Iatissima Miq Mesocarp.

\begin{tabular}{cc}
\hline Duration & $\begin{array}{c}\text { Total Flavonoid Content } \\
\text { (mgQE/one gram extract) }\end{array}$ \\
\hline 5 Minutes & 17,61 \\
10 Minutes & 31,24 \\
15 Minutes & 29,85 \\
\hline
\end{tabular}

Table 6: Total Phenolic compound of Water Extract G. Iatissima Miq Mesocarp.

\begin{tabular}{cc}
\hline Duration & $\begin{array}{c}\text { Total Phenolic Extract } \\
\text { (mg GAE/one gram extract) }\end{array}$ \\
\hline 5 Minutes & 12,04 \\
10 Minutes & 4,64 \\
15 Minutes & 21,61 \\
\hline
\end{tabular}

\section{Determination of Total Flavonoid Content}

Determination of Total Flavonoid Content was calculated used quercetin as standard. A Six concentration quercetin solution was used to made curve calibration and was obtained quercetin calibration curve with $\mathrm{y}=0,0618 \mathrm{x}+0,0216$ and correlation values $(\mathrm{r})$ is 0,99919 . Total flavonoid content was stated in QE (Quercetin Equivalent). Total flavonoid content of water extract of G. latissima Miq. mesocarp can be seen in Table 5 . Based on the test, 10 min infusion water extract had highest total flavonoid content i.e $31,24 \mathrm{mg} \mathrm{QE} /$ one gram extract.

\section{Determination of Total Phenolic Content}

This test used Galic Acid as Standard Solution. A six standard solution concentration was used to determine gallic acid calibration curve and was obtained linear regression with $y=0,0855 x+0,0442$ and $r=0,99934$. The total phenolic compound was stated as GAE (Galic Acid Equivalent). Total phenolic compound of water extract G. latissima Miq. Mesocarp can be seen in Table 6. Based on the test, 15 min infusion water extract had highest total phenolic content i.e 21,61 mg GAE/ one gram extract.

\section{Hedonic test}

Herbal tea of G. latissima Miq. mesocarp was made into two formula. Formula B was sweetener than formula A. The colour of formula A is pink and the colour of Formula B is yellowish pink. The odor of both formulas was similar. Based on statistics, it showed there was no significant difference to the colour, odor and taste of the two formula. Hedonic test result of Herbal Tea can be seen in Table 7.

\begin{tabular}{ccc} 
Table 7: Hedonic test result of Herbal Tea. & Taste & \\
\hline & Formula A & Formula B \\
\hline Hedonic Scale & $13 \%$ & $13 \%$ \\
\hline Dislike & $24 \%$ & $13 \%$ \\
Neutral & $30 \%$ & $7 \%$ \\
Like slightly & $20 \%$ & $50 \%$ \\
Like & $13 \%$ & $10 \%$ \\
Like Very much & $0 \%$ & $7 \%$ \\
\hline Like Extremely & Colour & \\
\hline & Formula A & Formula B \\
\hline Hedonic Scale & $3 \%$ & $7 \%$ \\
\hline Dislike & $0 \%$ & $3 \%$ \\
Neutral & $17 \%$ & $20 \%$ \\
\hline Like slightly & $30 \%$ & $40 \%$ \\
Like & $23 \%$ & $20 \%$ \\
\hline Like Very much & $27 \%$ & $10 \%$ \\
\hline Like Extremely & Odor & \\
\hline & Formula A & Formula B \\
\hline Hedonic Scale & $0 \%$ & $24 \%$ \\
\hline Dislike & $37 \%$ & $3 \%$ \\
Neutral & $23 \%$ & $34 \%$ \\
\hline Like slightly & $30 \%$ & $23 \%$ \\
Like & $7 \%$ & \\
\hline Like Very much & $3 \%$ & \\
Like Extremely & & \\
\hline & & $34 \%$ \\
\hline
\end{tabular}

\section{DISCUSSION}

\section{Characterization of Simplicia}

Characterization of simplicia was done to guarantee the quality of simplicia. Simplicia is a dry pink colour, sour taste and no odor. Determination of water soluble extract content was aimed to know an amount of the extract that can soluble in water. ${ }^{12}$ Determination of ethanol soluble extract content was aimed to show an amount of the extract that can soluble in ethanol. ${ }^{12}$ Determination of total ash was aimed to show the content of mineral content in simplicia. On this test, the sample was burned at a specific temperature where organic compound and its derivate are destructible and evaporate, so it remains mineral and inorganic content. ${ }^{12}$ Determination of ash insoluble-acid showed the amount of mineral content that insoluble in acid. Determination of loss on drying was aimed to show the amount of compound that lost on drying. At G. latissima Miq. simplicia had the loss on drying valued around $3,13 \pm 0,27 \%$. It was met the requirements of loss on drying of brewing simplicia powder i.e maximal $10 \% .{ }^{13}$

\section{Extraction}

Extraction of G. latissima Miq. mesocarp using infusion method was done because this method is most closely related to the tea brewing process. A number of simplicia extracted and solvent used was adjusted to the content of simplicia powder in a tea bag and water used to brew tea. Based on the result, optimal yield presentation was obtained at $10 \mathrm{~min}$ infusion extraction and decreased on $15 \mathrm{~min}$ infusion. The same pattern also occurred in the previous study, in that study the extension of extraction time cause the yield to rise in the $15^{\text {th }}$ min and then decreased at the $30^{\text {th }}$ min. ${ }^{14}$ It is suspected to occur because on 10 min infusions extract there are compounds in the plant that decomposes. In addition, it can also be due to errors during the extraction process ie there are extracts remaining in the container so that the yield obtained is reduced. 


\section{HMG-CoA Reductase Inhibitory Activity Test}

A preliminary test to determine $\mathrm{IC}_{50}$ pravastatin was done to ensure the method used is valid. The low percentage of inhibitory activity may be caused by the lack of methods and solvents used, so the compound that could inhibit HMG-CoA reductase enzyme was not perfectly extracted.

Based on the result, a 10 min infusion extract had the highest inhibitory the activity and then decreased on 15 min infusion extract. This might happened because in $10 \mathrm{~min}$ infusion extract, the component that could inhibit activity of HMG-CoA reductase enzyme had been completely extracted and in a 15 min infusion extract the component had been degraded. In addition, the decreasing in inhibitory activity might be caused by decreasing of the compound content that might has inhibitory activity, such as flavonoid. Decreasing of the compound content is caused by prolonged extraction time. ${ }^{15}$ Total flavonoid content in this study also had the same pattern with inhibitory activity percentage.

\section{Chromatogram Profile}

Chromatogram profile was aimed to show an overview of chemical content from the extract. Chromatogram profile was used quercetin as standard, silica gel $60 \mathrm{~F}_{254}$ as stationary phase, phase Chloroform P-Acetone P-Formic Acid (10:2:1) as mobile phase.The Plat that had been elucidated, it was sprayed by using $\mathrm{AlCl}_{3}$ and was observed in UV Light $366 \mathrm{~nm}$. $\mathrm{AlCl}_{3}$ show all 5-hydroxy-flavonoid as fluorescence spot under UV light $366 \mathrm{~nm} .{ }^{16}$

\section{Determination of Total Flavonoid Content}

Determination of Total Flavonoid Content was performed by using FHI method. Aluminium chloride and Sodium acetate were added in this method. Aluminium chloride forms acid stable complexes with C-4 keto group and also C-3 or C-5 hydroxyl group of flavones and flavonols. Aluminium chloride also forms acid labile with the ortho-dihydroxyl groups in the ring A-or B of flavonoids. ${ }^{17}$ The addition of sodium acetate causes ionization of the most acidic hydroxyl groups of flavonoid, sodium acetate is used to detect free 7-hydroxyl group. In flavonol addition of Aluminium chloride will cause a bathochromic shift 35 to $55 \mathrm{~nm}$, while the addition of sodium acetate will cause a 5 to $20 \mathrm{~nm}$ bathochromic shift. ${ }^{16}$ The complexes between Aluminum chloride and flavonol in the C-3 and C-4 hydroxyl groups and also in the ortho-dihydroxyl group have maximum absorption at wavelengths of $415-440 \mathrm{~nm} \cdot{ }^{17}$ In this study, the maximum wavelength obtained was at $437 \mathrm{~nm}$.

Based on the result showed that the total flavonoid content in $10 \mathrm{~min}$ infusion extract is the highest total flavonoid content then total flavonoid content decreased in the extract of 15 min infusion extract. This might happen because in $10 \mathrm{~min}$ infusions had been completely extracted and in $15 \mathrm{~min}$ infusions extract the component had been degraded. Previous studies have shown that prolonged extraction time can reduce total flavonoid content, as in routine compounds ${ }^{18}$ and also in catechins. ${ }^{15}$

\section{Determination of Total Phenolic Content}

Determination of total phenolic content was performed on all three extracts. In the Folin-Ciolcateu Phenol method, sample was added Folin-Ciolcalteu Phenol reagent, then was incubated for $8 \mathrm{~min}$ and then was added $\mathrm{NaOH} 1 \%$. Reagent Folin-Ciolcalteu Phenol contains tungstate and molybdate $6^{+}$oxidation number. When reagents was added to sample, molybdate will reduction so it will change from yellow to blue. The reaction occurs slowly in the acidic atmosphere. ${ }^{19}$ The addition of $\mathrm{NaOH} 1 \%$ to sample will provides an alkaline atmosphere which accelerates the process of reduction reaction on molybdate. ${ }^{19}$

The result showed that total phenol content decreased on 10 min infusion extract and increased on 15 min infusion extract. it was suspected that total phenol content in $10 \mathrm{~min}$ infusion extract had been degraded.
The previous study showed that total phenolic compound in Thymus vulgaris had been decreased since the $5^{\text {th }} \mathrm{min}$ in the extraction condition at $100^{\circ} \mathrm{C} .{ }^{14}$ Increasing total phenolic compound in 15 min infusion extracted might be caused by other components such as carbohydrates, that had been extracted and the component also affects total phenol content. ${ }^{14}$ Folin-Ciolcateu also can react with other components such as protein, carbohydrate amino acid, nucleotide, unsaturated fatty acid, vitamin, amine, aldehyde and ketone. ${ }^{20}$

\section{Hedonic Test}

Herbal tea of G. latissima Miq. was made in two formula. Formula A was not added by sweetener and formula B was added by sweetener. Sweetener which was used is dry Stevia leaf (Stevia rebaudiana). Stevia leaves were chosen because stevia leaves were one of the natural sweeteners that have been widely used as sugar substitutes. ${ }^{21}$ In this study required the amount of stevia which is equivalent to $10 \mathrm{~g}$ of sucrose. The stevia leaves have a sweetness level 20-30 times higher than sucrose. ${ }^{21}$ Therefore, the required amount of stevia was about $0.333-0.5 \mathrm{~g}$, so in the formula $\mathrm{B}$ added stevia as much as approximately $0.35 \mathrm{~g}$.

The hedonic test was performed on non-standard panellist or untrained panellits. Non-standard panellists are people who have not been trained in organoleptic/sensory assessment. The minimum number of nonstandard panellists on hedonist testing is 30 people, so in this study using non-standard panellists of 30 people. ${ }^{22}$

\section{CONCLUSION}

Based on this study, it can be concluded that water extract of G. latissima Miq mesocarp has a low potency in HMG-CoA reductase inhibitory activities.

\section{ACKNOWLEDGEMENT}

Thanks to PITTA Grant University of Indonesia that funding this research.

\section{CONFLICT OF INTEREST}

The authors declare no conflict of interest.

\section{ABBREVIATIONS}

DMSO: Dimethyl sulfoxide; NADPH: Nicotinamide adenine dinucleotide Phosphate Hydrogen; HMG-CoA: 3-Hydroxy-3-methylglutaryl coenzyme A; FHI: Farmakope Herbal Indonesia.

\section{REFERENCES}

1. Murray RK,Granner DK, Rodwell WW. Biokimia Harper (27th ed). Jakarta: EGC. 2009.

2. Brunton LL, Laza JS, Parker KL. Goodman and Gillman's The Pharmacological Basis of Therapeutics ( $11^{\text {th }}$ ed). United States of America: Mc Graw Hill. Brazilan Journal of Pharmacognosy. 2006.

3. LIPI. Review: Keanekaragaman Jenis Buah-Buahan Asli Indonesia dan Potensinya. Biodiversitas. 2007;8(2):157-67.

4. Chairungsrilerd N, Furukawa K, Ohta T, Nozoe S, Ohizumi,Y. Histaminergic and serotonergic receptor blocking substances from the medicinal plant Garcinia mangostana. Planta Med. 1996;62(5):471-2.

5. Verma A, Singh A. Optimization and Quality Assessment of Low-Calorie Herbal Health Tea Sweetened with Stevia (Stevia Rebaudiana). JMRD. 2014;3(2):134-7.

6. Ritthiwigrom T, Laphookhieo S, Pyne SG. Chemical constituents and biological activities of Garcinia cowa Roxb. Maejo. International Journal of Science and Technology. 2013;7(2):212-31.

7. Tuansulong $\mathrm{K}$, Towatana $\mathrm{N} \mathrm{H}$, Mahabusarakam W, Pinkaew D, Fujise $\mathrm{K}$ Morelloflavone from Garcinia dulcis as a Novel Biflavonoid Inhibitor of HMG CoA Reductase. Phytotherapy Research. 2011;25(3):424-8.

8. Departemen Kesehatan Republik Indonesia. Materia Medika Indonesia Jakarta: Departemen Kesehatan Republik Indonesia. 1989;5.

9. Perchellet JH, et al. Novel synthetic inhibitors of 3-hydroxy-3-methylglutarylcoenzyme A (HMG-CoA) reductase activity that inhibit tumor cell proliferation and are structurally unrelated to existing statin. Int J Mol Med. 2009;24(5):633-43.

10. Iqbal D, Khan MS, Khan MS, Ahmad S, Hussain MS, Ali M. Bioactivity guided 
fractionation and hypolipidemic property of a novel HMG-CoA reductase inhibitor from Ficus virens Ait. Lipids In Heallth and Disease. 2015;14(1):15

11. Hafidz KA. Uji Aktivitas Penghambatan HMG CoA Reduktase dan Penetapan Kadar Resveratrol dari Ekstrak-Ekstrak Biji Melinjo (Gnetum gnemon L.). Skripsi. 2016.

12. Indonesia D. Parameter Standar Umum Ekstrak Tumbuhan Obat. Jakarta: Departemen Kesehatan Republik Indonesia. 2000:9-12.

13. BPOM. Persyaratan Mutu Obat Tradisional. Indonesia. 2014.

14. Salinas JRV, Jimênez JP, Torres JL, Agosin E, Correa JRP. Effects of Temperature and Time on Polyphenolic Content and Antioxidant Activity in the Pressurized Hot Water Extraction of Deodorized Thyme (Thymus vulgaris). J Agric Food Chem. 2012;60(44):10920-29.

15. Uzulanic AP, Škerget M, Knez Ž, Weinreich B, Otto F, Gruner S. Extraction of active ingredients from green tea (Camellia sinensis): Extraction efficiency of major catechins and caffeine. Food Chemistry. 2006;96(4):596-605.

16. Markham KR. Cara Mengidentiifikasi Flavonoid. Bandung: Penerbit ITB.1998.
17. Chang $C$, Yang M, Wen $H$, Chern J. Estimation of total flavonoida content in propolis by two complementary colorimetric methods. Journal of Food and Drug Analysis. 2002;10(3):178-82.

18. Silveira TFF, Meinhart AD, Ballus CA, Godoy HT. The effect of the duration of infusion, temperature and water volume onthe rutin content in the preparation of mate tea beverages: An optimization study. Food Research International. 2013

19. Agbor GA, Vinson JA, Donnelly PE. Folin-Ciocalteau Reagent for Polyphenolic Assay. Int J Food Sci Nutr Diet. 2014;3(8):47-156.

20. Everrette JD, Bryant QM, Green AM, Abbey YA, Wangila GW, Walker RB Thorough Study of Reactivity of Various Compound Classes toward the FolinCiocalteu Reagent. J Agric Food Chem. 2010;58(14):8139-44.

21. Madan, Ahmed, Singh, Kohli, Singh, Garg D. Stevia reabudiana (Bert.) Bertoni - A Review. Indian Journal of Natural Products and Resources. 2010;10(3):178-182.

22. Standar Nasional Indonesia. Petunjuk pengujian organoleptik dan atau sensori. Badan Standar Nasional. 2006.

\section{GRAPHICAL ABSTRACT}

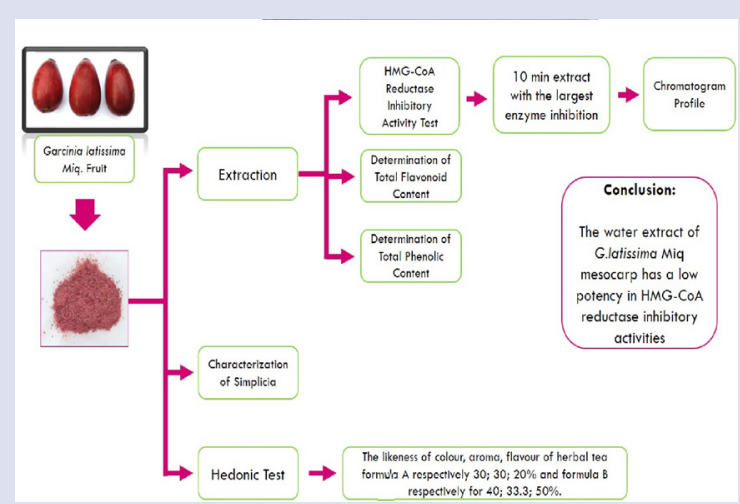

\section{ABOUT AUTHORS}

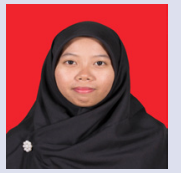

Herra Williany Monalissa: Undergraduate Student from Faculty of Pharmacy, University of Indonesia Enrolling Apothecary Program in Faculty of Pharmacy University of Indonesia

\section{SUMMARY}

- High cholesterol in the blood is a risk factor for atherosclerosis that causes various diseases. The main pharmacologic intervention to reduce cholesterol levels is inhibiting the HMG-CoA reductase enzyme. One of the genera of Garcinia, Garcinia dulcis, has potential as an anti-cholesterol. Based on chemotaxonomy, Garcinia latissima Miq. is also estimated to have a potency as anti-cholesterol. This study aims to test the inhibition of HMG-COA reductase water extract activity of $G$. latissima fruit flesh with different duration of infusions. Garcinia latissima Miq. mesocarp was extracted using infusion method with different duration of infusions. Each of extracts was tested the inhibitory activity of HMGCoA reductase as well as the determination of total flavonoid and total phenol content. In addition, the simplicia of the mesocarp of G.latissima Miq. will be made as a herbal tea and a hedonic test is performed to find out the degree of liking for the tea. The test results showed the inhibitory activity of $100 \mathrm{ppm}$ G. latissima Miq. mesocarp water extract with infusion for 5, 10 and $15 \mathrm{~min}$ respectively $11.32 ; 29.02 ; 13.03 \%$. The $10 \mathrm{~min}$ extract with the largest enzyme inhibition had total flavonoids content of $31.24 \mathrm{mg} \mathrm{QE} \mathrm{/} \mathrm{gram} \mathrm{extract} \mathrm{and} \mathrm{total}$ phenol content of $4.64 \mathrm{mg} \mathrm{GAE} /$ gram extract. The result of the hedonic test for the colour, aroma, flavour of herbal tea formula A respectively $30 ; 30 ; 20 \%$ and formula B respectively for $40 ; 33.3 ; 50 \%$. The water extract of G.latissima Miq mesocarp has a low potency in HMG-CoA reductase inhibitory activities.

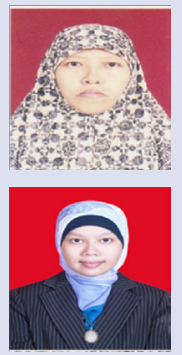

Berna Elya: Lecturer, Supervisor, and Laboratory of Phytochemistry and Pharmacognos, Faculty of Pharmacy, Universitas Indonesia.

Nuraini Puspitasari: Lecturer, Supervisor, and Laboratory of Phytochemistry and Pharmacognos, Faculty of Pharmacy, Universitas Indonesia.

Cite this article: Monalissa HW, Elya B, Puspitasari N. HMG-CoA Reductase Inhibitory Activity of Garcinia latissima Miq. Mesocarp Water Extract for Herbal Tea. Pharmacog J. 2018;10(6)Suppl:s141-s146. 